\title{
Effect of maize processing on diet selection by bovine*
}

\author{
P.H.M. Rodrigues ${ }^{1}$, F.A. Ferreira ${ }^{1}$, R. Passini ${ }^{1}$, \\ L.M.O Borgatti ${ }^{2}$ and P.M. Meyer ${ }^{3}$
}

\author{
${ }^{1}$ College of Veterinary Medicine and Animal Science, University of Sao Paulo-USP, Brazil \\ ${ }^{2}$ Nuclear Energy Center for Agriculture, University of Sao Paulo-USP, Brazil \\ ${ }^{3}$ Brazilian Institute of Geography and Statistics-IBGE, Brazil
}

\begin{abstract}
Effects of maize processing on diet selection was studied in 12 fistulated dry cows. Subexperimental period was repeated twice ( 8 animals/treatment) and lasted 20 days. Treatments allowed selection between roughage and processed maize: (CG) coarsely-ground, (FG) finely-ground and (SF) steam-flaked. Urea was used with sugar cane (10\% of crude protein) to avoid $\mathrm{N}$ influence over selection. Intake of maize in SF was 45.1 and $42.1 \%$ lower than in CG and FG, decreasing total DM and TDN intake, and increasing NDF intake. However, degradable starch intake did not differ. Animals were able to recognize differences among maize physical characteristics.
\end{abstract}

KEY WORDS: steam-flaking, voluntary feed intake, cattle, preferences, maize

\section{INTRODUCTION}

The concept of processing grains involves increase of starch availability for enzymatic attack by ruminal microbiota and by the host. Methods as steamflaking, which combines heat and humidity, result in increase of grain superficial area with increase of starch digestibility (Theurer et al., 1995).

Forbes (1995) summarized many studies involving the hypothesis that animals would be able to distinguish differences among feedstuffs and that they would be capable of choosing the most compatible diet with their physiological status (growth, gestation, lactation). Such choices would be based not only on sensorial perceptions, but also on nutritional composition of feed.

\footnotetext{
* Supported by FAPESP and CNPq (Brazil)

${ }^{1}$ Corresponding author: e-mail: pmazza@usp.br
} 
The aim of the present study was to relate nutritional differences among maizes processed in different ways to the hypothesis that animals could perceive such differences, being able to balance their energy intake.

\section{MATERIAL AND METHODS}

Twelve non-pregnant and non-lactating Holstein cows ( $650 \mathrm{~kg}$ of body weight) with ruminal cannula were housed in individual stalls with subdivided feed bunks, which allowed evaluating feed intake separately.

A randomised block design formed in function of BW and experimental period was used. Sub-experimental period was repeated twice, performing 8 animals per treatment. Treatments corresponded to different methods of maize grain processing, available for animals to manifest their preferences: (CG) sugar cane plus urea and coarsely ground maize (1.6 mm of average particle size-APS), (FG) sugar cane plus urea and finely ground maize $(0.8 \mathrm{~mm}$ of APS) and (SF) sugar cane plus urea and steam-flaked maize ( $8.25 \mathrm{~mm}$ of APS and density of $270 \mathrm{~g} / \mathrm{L})$.

Sugar cane plus urea $(10 \% \mathrm{CP})$ and maize were supplied ad libitum. Twice daily, at $08.00 \mathrm{~h}$ and $16.00 \mathrm{~h}, 40 \mathrm{~g}$ of mineral supplement and $40 \mathrm{~g}$ of a mixture of urea and ammonium sulphate were administered directly inside the rumen of each animal ( $80 \mathrm{~g}$ of each mixture/day/animal), in order to avoid that preference would be influenced by minerals needs and to avoid nitrogen deficiency, respectively.

Identification if processing method influenced choice process was accomplished through comparison of chemical composition of diets selected by animals.

Each sub-experimental period lasted 20 days. From day -5 to -1 , animals received only roughage diet. From day 0 up to day 14, maize was added to animals' diet. During the whole period ( -5 day until 14 day), individual intake of all available ingredients was measured. Final intake was obtained from average intake among days 11 and 14.

On day 14 , just prior to morning meal $(0 \mathrm{~h})$ and at $3,6,9$ and $12 \mathrm{~h}$ postfeeding, samples of ruminal fluid were taken to proceed determination of $\mathrm{pH}$, ammonia nitrogen by colorimetry and VFA by gas chromatography.

Analysis of variance separated as variation sources the effects of treatments, blocks and periods. Separation of means was done using LSD test, chosen due to its high sensibility, recommended when the objective is to demonstrate equality among treatments (Lentner and Bishop, 1993).

\section{RESULTS AND DISCUSSION}

Animals that received treatment SF consumed 45.1 and $42.1 \%$ less concentrate in $\mathrm{kg}$ than animals from treatments CG and FG (Table 1), respectively. This resulted in decreases of 24.5 and $22.6 \%$ in total DM intake, 29.8 and $27.6 \%$ in 
TDN intake in $\mathrm{kg}, 9.3$ and $8.6 \%$ in TDN intake in percentage and increases of 45.7 and $47.2 \%$ in NDF intake in percentage, respectively. In this trial, a fixed value was used to estimate maize TDN.

The decrease of concentrate intake and, consequently, of DM may be explained by starch physical characteristics, resulting higher amount of available energy, in steam-flaked maize than in the other dry processed maizes used in this trial.

With the increase of energy availability, the decrease of concentrate intake by animals from treatment SF may be explained by the theory of metabolic limitation (Conrad, 1966) or related to the process of physiopathological control in the rumen, where increase in acids production would be one of the factors responsible for intake control in those animals (Van Soest, 1994).

Another possibility to explain changes in selected diet is that animals refused the physical appearance of steam-flaked maize. However, it is possible to suspect that animals were able to chose their diet in function of available energy instead of maize physical appearance once degradable starch intake of the three groups did not differ significantly.

Table 1. Daily mean intake of feed and nutrients by selection from different treatments

\begin{tabular}{|c|c|c|c|c|c|}
\hline \multirow{2}{*}{ Nutrient intake } & \multicolumn{3}{|c|}{ Treatments $^{1}$} & \multirow{2}{*}{ C.V. } & \multirow{2}{*}{ Prob. } \\
\hline & $\mathrm{CG}$ & FG & SF & & \\
\hline Total DM, kg & $10.40^{\mathrm{a}}$ & $10.14^{\mathrm{a}}$ & $7.85^{\mathrm{b}}$ & 24.42 & 0.0448 \\
\hline Concentrate, $\mathrm{kg}$ & $7.72^{\mathrm{a}}$ & $7.32^{\mathrm{a}}$ & $4.24^{\mathrm{b}}$ & 41.58 & 0.0102 \\
\hline$\%$ & $72.97^{\mathrm{a}}$ & $70.92^{\mathrm{a}}$ & $47.20^{\mathrm{b}}$ & 33.94 & 0.0218 \\
\hline Roughage, kg & 2.65 & 2.82 & 3.53 & 43.33 & NS \\
\hline NDF, kg & 2.49 & 2.41 & 2.59 & 24.77 & NS \\
\hline$\%$ & $24.66^{\mathrm{b}}$ & $24.41^{\mathrm{b}}$ & $35.93^{\mathrm{a}}$ & 33.92 & 0.0159 \\
\hline TDN, kg & $8.08^{\mathrm{a}}$ & $7.83^{\mathrm{a}}$ & $5.67^{\mathrm{b}}$ & 27.96 & 0.0224 \\
\hline$\%$ & $77.46^{\mathrm{a}}$ & $76.90^{\mathrm{a}}$ & $70.26^{\mathrm{b}}$ & 8.07 & 0.0219 \\
\hline Degradable starch, kg & 2.25 & 2.60 & 2.05 & 39.27 & NS \\
\hline$\%$ & 21.26 & 25.13 & 22.84 & 36.89 & NS \\
\hline Degradable DM, kg & 4.44 & 5.25 & 4.41 & 24.62 & NS \\
\hline$\%$ & $42.89^{c}$ & $51.71^{\mathrm{b}}$ & $55.04^{\mathrm{a}}$ & 11.89 & 0.0001 \\
\hline
\end{tabular}

${ }^{1} \mathrm{DM}$ - dry matter; NDF - neutral detergent fibre; TDN - total digestible nutrient; C.V. - coefficients of variation; Prob. - statistical probabilities; NS - non-significant

Additionally, besides the large difference between quantity and composition of selected diet, ruminal fermentation did not differ too much between treatments, indicating that animals were able to keep rumen environment constant. 
Table 2. Ruminal fermentation pattern obtained with treatments

\begin{tabular}{|c|c|c|c|c|c|c|}
\hline & \multicolumn{3}{|c|}{ Treatments } & \multirow{2}{*}{ C.V. } & \multicolumn{2}{|c|}{ Probabilities $^{1}$} \\
\hline & $\mathrm{CG}$ & $\mathrm{FG}$ & $\mathrm{SF}$ & & Treat. & Time $\times$ Treat \\
\hline $\mathrm{pH}$ & 6.14 & 6.25 & 6.24 & 5.59 & NS & NS \\
\hline Total VFAs, mM & 102.35 & 97.99 & 98.50 & 16.47 & NS & NS \\
\hline Acetic, molar $\%$ & 64.98 & 61.40 & 66.01 & 9.39 & NS & NS \\
\hline Propionic, molar $\%$ & $25.49^{\mathrm{ab}}$ & $28.68^{\mathrm{a}}$ & $22.43^{b}$ & 23.08 & 0.0841 & NS \\
\hline Butyric, molar\% & 9.52 & 9.92 & 11.56 & 33.23 & NS & NS \\
\hline Acet./Prop. Ratio & $2.79^{\mathrm{ab}}$ & $2.23^{\mathrm{b}}$ & $3.06^{\mathrm{a}}$ & 30.67 & 0.0722 & NS \\
\hline $\mathrm{NH}_{3}-\mathrm{N}, \mathrm{mg} / \mathrm{dL}$ & 4.66 & 3.87 & 4.18 & 113.81 & NS & NS \\
\hline
\end{tabular}

${ }^{1}$ Treat. - probability for treatment effect; Time $\times$ Treat - probability for time $\times$ treatment interaction effect, C.V. - coefficients of variation; NS - non-significant

\section{CONCLUSIONS}

Offering to bovines the opportunity to choose ingredients differing in physical characteristics, it was observed that choices were non-random and degradable starch intake was kept constant.

\section{REFERENCES}

Conrad H.R., 1966. Symposium on factors influencing the voluntary intake of herbage by ruminants: Physiological and physical factors limiting feed intake. J. Anim. Sci. 25, 227-235

Forbes J.M., 1995. Voluntary food intake and diet selection in farm animals. CAB International, Wallingford, pp. 532

Lentner M., Bishop T., 1993. Experimental Design and Analysis. Valley Book Company, Blacksburg, pp. 585

Theurer C.B., Huber J.T., Santos F.A.P., 1995. Feeding and managing for maximal milk protein. In: Proceedings of Southwest Nutrition and Management Conference. Department of Animal Science, University of Arizona, Tucson, p. 176

Van Soest P.J., 1994. Nutritional Ecology of the Ruminant. Cornell University Press, Ithaca, NY 